Bangladesh J. Zool. 48(1): 119-125, 2020

ISSN: 0304-9027 (print)

2408-8455 (online)

\title{
GASTROINTESTINAL PARASITES OF CAPTIVE ASIATIC BLACK BEAR IN THREE ZOOLOGICAL PARKS OF BANGLADESH
}

\author{
Fahmida Tasnim Liza*, Mandira Mukutmoni and Aleya Begum \\ Department of Zoology, Faculty of Biological Sciences, University of Dhaka \\ Dhaka, Bangladesh
}

\begin{abstract}
Forty-two freshly defecated fecal samples from captive Asiatic Black Bear (Ursus thibetanus) were collected between May 2017 and April 2018 from Bangladesh National Zoo, Dhaka, Shaheed A.H.M. Central Park and Zoo, Rajshahi and Bangabandhu Sheikh Mujib Safari Park, Gazipur. The collected samples were processed by Formol-ether concentration technique. Altogether nine different gastrointestinal (GI) parasites were observed and identified, which include one protozoan, Coccidia spp. (42.86\%); four cestodes, Hymenolepis spp. (42.86\%), Diphyllobothrium spp. (28.57\%), Spirometra spp. (14.29\%) and Taenia spp. (21.43\%); and four nematodes Ascaris spp. (57.14\%), Toxocara spp. (21.43\%), Trichuris spp. (21.43\%) and hookworms (35.71\%). No trematode parasite was found during the study period. Dominance of helminth parasites $(71.43 \%)$ over protozoan parasites was observed. The male bears were found more susceptible to parasitic infection than the females. The intensity of infection was found erratic in young and adult bears. The species diversity, animals feeding behavior and hygiene maintenance may be responsible for the high prevalence rate of gastrointestinal parasites in the present study.
\end{abstract}

Keywords: Gastrointestinal (GI) parasites, Captive animals, Asiatic Black Bear, Zoo, Bangladesh

Zoological gardens are important to educate the general public about wildlife and their habitats as well as preserve critically endangered species through captive breeding and reintroduction (Schulte-Hostedde and Mastromonaco 2015). Gastrointestinal (GI) parasites sometimes affect mammals severely causing diarrhea. The stress in caged or confined animals causes deterioration to their immunological system which makes them more vulnerable to parasitic infection; whereas contamination rarely occurs to them in natural conditions. Sanitation, feeding management and gathering inside the cage also influence in increasing endoparasites among zoo animals (Malan et al. 1997). Fecal examination or coprological analysis is a safe method to understand the parasitic conditions of free ranging wildlife (Shirbhate 2006). It provides information on the overall health condition of animals, such ascomposition of diet, load of gastrointestinal parasites, prey preference as well as ecological significance (Patton et al. 1986). It is also important to study the parasitic dynamics in wild populations as it can transfer to domestic animals and even to humans (Shirbhate 2006). Asiatic black bear (Ursus thibetanus) is now a critically endangered species of Bangladesh (IUCN 2015). But studies on parasitic infestation in black bears are very limited here and data deficient, as very few methodical studies had been undertaken. To conduct a fruitful conservation program, health screening is required as there is a growing recognition of parasites as a major factor in the biology and conservation of species (Smith et al. 2009). The goal of the present study is to investigate age, sex and season-based prevalence and intensity of gastrointestinal parasites in Asiatic black bear present in three different zoological parks of Bangladesh.

"Author for corresponding <fahmida_2428@yahoo.com>

(C2020 Zoological Society of Bangladesh DOI: https://doi.org/10.3329/bjz.v48i1.47881 


\section{MATERIAL AND METHODS}

Forty-two freshly defecated fecal samples of Asiatic black bears were collected during May 2017 to April 2018 from Bangladesh National Zoo, Dhaka $\left(23^{\circ} 48^{\prime} 44^{\prime \prime N}\right.$, $\left.90^{\circ} 20^{\prime} 48^{\prime \prime E}\right)$, Shaheed A.H.M. Central Park \& Zoo, Rajshahi $\left(24^{\circ} 22^{\prime} 02 " \mathrm{~N}, 88^{\circ} 34^{\prime} 13^{\prime \prime} \mathrm{E}\right)$

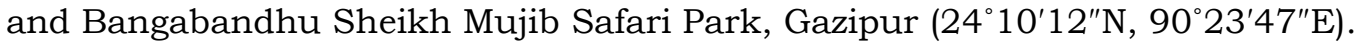

In the early morning, the fresh fecal samples were collected with the help of cage caretakers. The collected fecal samples were stored into the pots containing $10 \%$ formalin. The pots were secured to avoid contamination and properly labeled indicating name, age group, sex and season. The age below or equal to five (Age $\leq 5$ ) years was considered as Age Group A (30 fecal samples); and age below or equal to ten years but older than five $(5<$ Age $\leq 10)$ years was considered as Age Group B (12 fecal samples).

The sample examination was done in the Parasitology Laboratory of the Department of Zoology, University of Dhaka. Samples were screened via Formol-Ether Concentration technique (Cheesbrough 1987); and calculated the number of eggs per gram (EPG) and cysts per gram (CPG) by Stoll's Egg Counting technique. The morphological identification of eggs and cysts was done following Chatterjee (1967), Soulsby (1982), Schmidt and Roberts (1996). To summarize the required results, prevalence, intensity and descriptive statistical analysis were used. Difference between the prevalence of parasites was determined using the regression test at $95 \%$ level of significance ( $p$ value $<0.05)$.

\section{RESULTS AND DISCUSSION}

Nine different gastrointestinal parasites were observed and identified during the present study. These include- one protozoan parasite (Coccidia spp.), four cestodes (Hymenolepis spp., Diphyllobothrium spp., Spirometra spp. and Taenia spp.) and four nematodes (Ascaris spp., Trichuris spp., Toxocara spp. and hookworms). No trematode was observed during the study period. The cause behind the absence of digenetic trematode in captive black bear can be justified by the complexity of this helminth life cycle which requires at least one intermediate host (a gastropod mollusc) to evolve which is not usually present in the habitat of these bears kept in captive condition.

In the present study, all the fecal samples were positive with GI parasites; i.e. the samples were screened positive for at least one parasite. Ascaris spp. showed the highest prevalence $(57.14 \%, \mathrm{n}=24 / 42)$ followed by Coccidia spp. $(42.86 \%, \mathrm{n}=18 / 42)$, Hymenolepis spp. $(42.86 \%, \mathrm{n}=18 / 42)$, hookworms $(35.71 \%, \mathrm{n}=15 / 42)$ and Diphyllobothrium spp. (28.57\%, n=12/42). However, Toxocara spp., Trichuris spp. and Taenia spp. showed the same prevalence of $21.43 \%(n=9 / 42)$. Spirometra spp. (14.29\%, $\mathrm{n}=6 / 42$ ) was screened as the least prevalent GI parasite in the study (Table 1). The factors that influence the survival, development, distribution or transmission of the free-living larvae seen on pasture, are normally weather related. The species diversity, animals feeding behavior and hygiene maintenance may be responsible for the excessive occurrence of gastrointestinal parasites during the study period. Again, all the animals do not harbor the same types of parasites; and perhaps for this reason the rate of the egg production varies. Alteration in the hosts' immunity due to lack of proper nutrition as well as stress can be responsible for this heavy parasitic load. Different geographical distribution and environmental conditions also may influence the parasite-host interaction. The favorable environment helps to spread the eggs of parasites as well as 
the disease quickly. On the other hand, improper anthelmintic treatment may also be responsible for the high prevalence of GI parasites in the present investigation.

In the present study, Hymenolepis spp., and Trichuris spp. were observed in black bears which usually infect rats, mice and other carnivores. The transmission of these parasite eggs to black bears can occur due to using the same equipment to clean the cage of different carnivores, like felids, canids etc. and also from the rat existence inside the bear cages. The bears might act as accidental host in this case. Hair and Mahrt (1970) reported two new species of Coccidia in wild American black bears of Alberta, Canada. Hatler (1967) and Worley et al. (1976) found the presence of Taenia in wild black bears in Central Alaska and Montana respectively; Stiles and Baker (1935) also identified Taenia spp. in captive Himalayan black bears (Selenarctos thibetanus) in India. The studies of Rausch et al. (1956) found two cestode species, Taenia hydatigena and Taenia krabbei from captive black bears in Alaska. From the bears of North America, only pseudophyllidean tapeworm, Diphyllobothrium sp. has been reported. Rausch (1954) described that bears can acquire these parasites by eating fish which contain plerocercoids. Additionally, species of Toxocara (T. canis and T.mystax) were isolated from the brown bears (Ursus arctos) in captivity of Bale, Germany (Couturier 1954). Lane (1916) recorded the presence of hookworm (Ancylostoma spp.) from Himalayan black bears in India and Sri Lanka.

In the present study, all the bears were female in Dhaka zoo and male in Rajshahi zoo. The intensity of parasites among the female bears in Dhaka zoo was lower $(10.67 \pm 6.47)$ than that of among the male bears (30.83 \pm 6.91$)$ in Rajshahi zoo. The bears of Rajshahi zoo were ill at the time of sampling. Among the male and female bears of Gazipur safari park, the males were more susceptible to infection than the female bears and the intensity was also higher in males $(19.33 \pm 1.53)$ than that in females $(15.44 \pm 5.29)$ (Table 2). According to Córdoba-Aguilar and Munguia-Steyer (2013), the males give more efforts in mating in different mating systems which would explain the male sex-bias in parasitic occurrence. Besides, the males happen to have exposed immune responses than females; as a result, they suffer more from parasitic disease (Zuk and Mckean 1996; Nunn et al. 2009). This male sex-bias parasitism may also be facilitated by testosterone-generated immunosuppressant described by Klein (2004).

Different strategies of anthelmintic drug administration are a prime cause behind high and low intensities of parasites. In Dhaka zoo, antihelminthic drugs are used twice in a year. In Rajshahi zoo, it is conducted every four months and every three months in Gazipur safari park. This drug administration did not show any specific result in the present study. Moreover, change in infection rate cannot be explained if no specific treatment is run. 
Table 1. Sex specific prevalence of GI parasites in Asiatic black bears

\begin{tabular}{|c|c|c|c|c|c|c|c|c|c|c|}
\hline $\begin{array}{l}\text { Study } \\
\text { Area }\end{array}$ & $\begin{array}{c}\text { Sex } \\
\text { (No. of } \\
\text { observe } \\
\text { d } \\
\text { sample } \\
\text { s) }\end{array}$ & $\begin{array}{l}\text { Coceidlas } \\
\text { spp. } \\
\text { (No. of } \\
\text { infected } \\
\text { sample } \\
\text { and \%) }\end{array}$ & $\begin{array}{l}\text { Ascaris } \\
\text { spp. } \\
\text { (No. of } \\
\text { infecte } \\
d \\
\text { sample } \\
\text { and \%) }\end{array}$ & $\begin{array}{l}\text { Hymenol } \\
\text { eplsspp. } \\
\text { (No. of } \\
\text { infected } \\
\text { sample } \\
\text { and \%) }\end{array}$ & $\begin{array}{l}\text { Diphyllobothriu } \\
\text { mspp. } \\
\text { (No. of infected } \\
\text { sample and } \% \text { ) }\end{array}$ & $\begin{array}{l}\text { Spirometrasp } \\
\text { p. } \\
\text { (No. of } \\
\text { infected } \\
\text { sample and } \\
\% \text { ) }\end{array}$ & $\begin{array}{c}\text { Toxocara } \\
\text { spp. } \\
\text { No. of } \\
\text { infected } \\
\text { sample and } \\
\text { y) }\end{array}$ & $\begin{array}{l}\text { Trichuris } \\
\text { spp. } \\
\text { (No. of } \\
\text { infected } \\
\text { sample and } \\
\text { \$) }\end{array}$ & $\begin{array}{l}\text { Tamiasp } \\
\text { (No. of } \\
\text { infected } \\
\text { sample } \\
\text { and \$) }\end{array}$ & $\begin{array}{l}\text { Hookwore } \\
m \\
\text { (No. of } \\
\text { infected } \\
\text { sample } \\
\text { and \%) }\end{array}$ \\
\hline $\begin{array}{l}\text { Ohata } \\
200\end{array}$ & $\begin{array}{l}\text { Female } \\
\text { (24) }\end{array}$ & $6(25)$ & $18(75)$ & $15(62.5)$ & $3(12.5)$ & . & $3(12.5)$ & 6 (ख) & $6(25)$ & $9(37 . \$)$ \\
\hline $\begin{array}{l}\text { Rajshahi } \\
200\end{array}$ & Male (6) & . & $6(100)$ & . & $6(100)$ & $6(100)$ & $6(100)$ & . & . & $6(100)$ \\
\hline Gazipur & Male [3] & $3(100)$ & . & . & . & . & . & $3(100)$ & . & . \\
\hline $\begin{array}{l}\text { Safari } \\
\text { park }\end{array}$ & $\begin{array}{c}\text { Femsio } \\
\text { (9) }\end{array}$ & $9(100)$ & . & $3(33.33)$ & $3(33.33)$ & . & . & . & $3(33.33)$ & . \\
\hline Overal & 42 & $\begin{array}{c}18 \\
(4285)\end{array}$ & $\begin{array}{c}24 \\
(52.14)\end{array}$ & $\begin{array}{c}18 \\
(4285)\end{array}$ & $12(28.57)$ & $6(14.29)$ & $9(21,43)$ & $9(21.43)$ & $9(21,43)$ & $\begin{array}{c}15 \\
(35.71)\end{array}$ \\
\hline
\end{tabular}

Table 2. Sex specific intensity of GI parasites in Asiatic black bears

\begin{tabular}{|c|c|c|c|c|c|}
\hline Study Area & $\begin{array}{l}\text { Age group (No. of } \\
\text { observed } \\
\text { samples) }\end{array}$ & $\begin{array}{c}\text { No. of } \\
\text { infected } \\
\text { sample }\end{array}$ & $\begin{array}{l}\text { EPG/ } \\
\text { CPG }\end{array}$ & $\begin{array}{c}\text { Intensit } \\
y \pm S D\end{array}$ & p value \\
\hline Dhaka zoo & Female (24) & 24 & 256 & $\begin{array}{c}10.67 \pm 6 . \\
47\end{array}$ & 0.001 \\
\hline Rajshahi zoo & Male (6) & 6 & 185 & $\begin{array}{c}30.83 \pm 6 . \\
91\end{array}$ & 0.05 \\
\hline \multirow[t]{2}{*}{$\begin{array}{c}\text { Gazipur } \\
\text { Safari park }\end{array}$} & Male (3) & 3 & 58 & $\begin{array}{c}19.33 \pm 1 . \\
53\end{array}$ & 0.05 \\
\hline & Female (9) & 9 & 139 & $\begin{array}{c}15.44 \pm 5 . \\
29\end{array}$ & 0.09 \\
\hline
\end{tabular}

In Dhaka zoo, among the bears of age Group A, the most prevalent parasite was Ascaris spp. (75\%), followed by Hymenolepis spp. (62.5\%), hookworms (37.5\%), Coccidia spp., (25\%), Diphyllobothrium spp. (12.5\%). and Toxocara spp. (12.5\%) (Table 3).The intensities of parasites were found significant $(\mathrm{p}<0.05)$ (Table 4).All the samples from Age Group A in Rajshahi zoo were infected with all the five helminths, Ascaris spp., Toxocara spp., hookworms, Spirometra spp., and Diphyllobothrium spp (Table 3). Unlike the other two study areas, in Gazipur safari park, higher prevalence of Coccidia spp. $(100 \%)$ was recorded among the bears of Age Group B (Table 3). Prevalence of helminth infection was low (each 25\%)(Table 3). The work of Simon et al. (2015) showed that the young and the aged are mostly prone to parasitic diseases, which develop severe infections and increase a high mortality rate compared to middle age groups. Although the occurrence was $100 \%$ in all age groups (Table 3), a different intensity level of parasites in bears was observed (Table 4). In Dhaka zoo, the bears of age Group A had comparatively low parasite burden $(10.67 \pm 6.47)$, as because they were kept separately in cages which prevented contamination. The male bears from Rajshahi zoo were ill at the time of sample collection and the intensity of infection was recorded high $(30.83 \pm 6.91)$ in it. In the Gazipur safari park, bears were well maintained and regular quarantine was done, which could be the reason behind the low intensity $(16.42 \pm 4.50)$ of GI parasites (Table 4).

The bears of Gazipur safari park showed high protozoan infection (100\%). They live in both outdoor open enclosures and cage. Another reason for the high prevalence of protozoans could be the temperature. For the effective sporulation of oocysts, the standard temperature is from $4{ }^{\circ} \mathrm{C}$ to $37^{\circ} \mathrm{C}$ and the optimal one is $29^{\circ} \mathrm{C}$ (Price et al. 
2014). All the samples were collected in summer from Gazipur safari park which was suitable for coccidian growth. Different species of Coccidia were found in captive carnivores at different Indian zoological gardens from the works of Singh et al. (2006), Mahali et al. (2010) and Ravindran et al. (2011). The primary climatic factors (temperature, humidity, rainfall) induce the prevalence of endoparasites (Gibbs 1982). In the present study, occurrence of GI parasites was $100 \%$ in summer and monsoon followed by winter (83.33\%) (Table 5). High temperature and optimum rainfall could be an important factor behind the result.

Table 3. Age specific prevalence of GI parasites in Asiatic black bears

\begin{tabular}{|c|c|c|c|c|c|c|c|c|c|c|}
\hline $\begin{array}{l}\text { Study } \\
\text { Area }\end{array}$ & $\begin{array}{l}\text { Age group } \\
\text { (No. of } \\
\text { observed } \\
\text { samples) }\end{array}$ & $\begin{array}{l}\text { Coccidiaspp. } \\
\text { (No. of } \\
\text { infected } \\
\text { sample and } \\
\% \text { ) }\end{array}$ & $\begin{array}{l}\text { Ascaris } \\
\text { spp. } \\
\text { (No. of } \\
\text { infected } \\
\text { sample } \\
\text { and \%) }\end{array}$ & $\begin{array}{l}\text { Hymenolepisspp } \\
\text { (No. of infected } \\
\text { sample and \%) }\end{array}$ & $\begin{array}{l}\text { Diphyllobothri } \\
\text { umspp. } \\
\text { (No. of infected } \\
\text { sample and \%) }\end{array}$ & $\begin{array}{l}\text { Spirometraspp } \\
\text { (No. of infected } \\
\text { sample and \%) }\end{array}$ & $\begin{array}{l}\text { Toxocara } \\
\text { spp. } \\
\text { (No. of } \\
\text { infected } \\
\text { sample and } \\
\% \text { ) }\end{array}$ & $\begin{array}{l}\text { Trichuris } \\
\text { spp. } \\
\text { (No. of } \\
\text { infected } \\
\text { sample and } \\
\% \text { ) }\end{array}$ & $\begin{array}{l}\text { Taeniaspp. } \\
\text { (No. of } \\
\text { infected } \\
\text { sample and } \\
\% \text { ) }\end{array}$ & $\begin{array}{l}\text { Hookworms } \\
\text { (No. of } \\
\text { infected } \\
\text { sample and } \\
\% \text { ) }\end{array}$ \\
\hline $\begin{array}{l}\text { Dhaka } \\
\text { zoo }\end{array}$ & $\begin{array}{l}\text { Age Group } \\
\text { A (24) }\end{array}$ & $6(25)$ & $18(75)$ & $15(62.5)$ & $3(12.5)$ & - & $3(12.5)$ & $6(25)$ & $6(25)$ & $9(37.5)$ \\
\hline $\begin{array}{l}\text { Rajshahi } \\
\text { zoo }\end{array}$ & $\begin{array}{c}\text { Age Group } \\
\text { A (6) }\end{array}$ & - & $6(100)$ & - & $6(100)$ & $6(100)$ & $6(100)$ & - & - & $6(100)$ \\
\hline $\begin{array}{l}\text { Gazipur } \\
\text { Safari } \\
\text { park }\end{array}$ & $\begin{array}{c}\text { Age Group } \\
\text { B (12) }\end{array}$ & $12(100)$ & - & $3(25)$ & $3(25)$ & - & - & $3(25)$ & $3(25)$ & - \\
\hline Overall & 42 & $18(42.86)$ & $\begin{array}{c}24 \\
(52.14)\end{array}$ & $18(42.86)$ & $12(28.57)$ & $6(14.29)$ & $9(21.43)$ & $9(21.43)$ & $9(21.43)$ & $15(35.71)$ \\
\hline
\end{tabular}

Table 4. Age specific intensity of GI parasites in Asiatic black bears

\begin{tabular}{lcccc}
\hline Study Area & $\begin{array}{c}\text { Age group } \\
\text { (No. of } \\
\text { observed } \\
\text { samples) }\end{array}$ & $\begin{array}{c}\text { No. of } \\
\text { infected } \\
\text { sample }\end{array}$ & EPG/ CPG & Intensity \pm SD \\
\hline Dhaka zoo & Age group A & 24 & 256 & $10.67 \pm 6.47$ \\
$\begin{array}{l}(24) \\
\text { Rajshahi zoo }\end{array}$ & $\begin{array}{c}\text { Age group A (6) } \\
\text { Gazipur Safari }\end{array}$ & 6 & 185 & $30.83 \pm 6.91$ \\
park & $\begin{array}{c}\text { group B } \\
\text { (12) }\end{array}$ & 12 & 197 & $16.42 \pm 4.50$ \\
\hline
\end{tabular}

Table 5. Seasonal occurrence of GI parasites in Asiatic black bears

\begin{tabular}{|c|c|c|c|c|}
\hline Season & $\begin{array}{c}\text { Total no. of } \\
\text { fecal samples } \\
\text { examined }\end{array}$ & $\begin{array}{l}\text { Total no. of } \\
\text { infected fecal } \\
\text { samples }\end{array}$ & $\begin{array}{c}\text { Prevalence } \\
\text { (\%) }\end{array}$ & p value \\
\hline Summer (March- June) & 12 & 12 & 100 & 0.30 \\
\hline Monsoon (July- October) & 12 & 12 & 100 & 0.43 \\
\hline Winter (November- February) & 18 & 15 & 83.33 & 0.16 \\
\hline
\end{tabular}

\section{CONCLUSION}

An improved control plan should implicate additional targeted approaches to manage parasites effectively limiting the pathogenic species by regular fecal examination along with administration of anticipated worm treatment at regular intervals. The Asiatic black bears kept in captivity need to be screened constantly as they are critical to handle and critically endangered in Bangladesh. Proper chemoprophylaxis for protection is also required.

Acknowledgements: The authors are indebted to the Ministry of Science and Technology, Government of Bangladesh for providing financial support to conduct the research work and 
grateful to the Forest Department of Bangladesh for permitting required accessibilities to the safari park. Special thanks to the following persons who have helped in the study- Professor Dr. Md. Anwarul Islam, Md. Mahabub Alam, Fazle Rabbe and Taniza Tabasshum of Department of Zoology, University of Dhaka; Dr. S.M. Nazrul Islam (Former Curator) of Bangladesh National Zoo, Dhaka; Farhad Uddin (Curator) of Shaheed A.H.M. Central Park and Zoo, Rajshahi; Md. Motaleb Hossain (Officer in Charge) and Dr. Md. Nizam Uddin Chowdhury (Assistant Surgeon, Veterinary) of Bangabandhu Sheikh Mujib Safari Park, Gazipur.

\section{LITERATURE CITED}

CHATTERJEE, K. D. 1967. Parasitology: (protozoology and helminthology) in relation to clinical medicine. Sree Saraswaty Press, India. 207-215 pp.

CHEesbROUGH, M. 1987. Medical Laboratory Manual for Tropical Countries. ELBS Publishing, UK. 427-570 pp.

CÓRDOBA-AGUILAR, A., and MUNGUÍA-STEYER, R. 2013. The sicker sex: Understanding male biases in parasitic infection, resource allocation and fitness. PLoS One.8(10): e76246.

COUTURIER, M.A.J. 1954. L'Ours Brun. Grenoble, France: Cours J. Jaures.

GIBBS, H.C. 1982. Mechanisms of survival of nematode parasites with emphasis on hypobiosis. Vet. Parasitol. 11: 25-48.

HAIR, J.D. and MAHRT, J.L. 1970. Eimaria albertensis n. sp. and E. borealis n. sp. (Sporozoa: Eimeridae) in black bears Ursus americanus from Alberta. J.Protozool.17: 663-664.

HATLER, D.F. 1967. Some aspects in the ecology of the black bear (Ursus americanus) in interior Alaska. MS thesis, University of Alaska Fairbanks. 111 pp.

IUCN BANGLADESH. 2015. Red List of Bangladesh: A Brief on Assessment Result 2015. IUCN, International Union for Conservation of Nature, Bangladesh Country Office, Dhaka, Bangladesh, pp. 24.

KLEIN, S.L. 2004. Hormonal and immunological mechanisms mediating sex differences in parasite infection. Oxford, UK. Parasit. Immunol.26: 247-264.

LANE, C. 1916. The genus Ancylostoma in India and Ceylon. Indian J. Med. Res.4: 74-92.

MAHALI, A.K., PANDA, D.N., PANDA, M.R., MOHANTY, B.N. and SAHOO, B. 2010. Incidence and seasonal variation of gastro-intestinal parasitic infections in captive carnivores in Nandankanan Zoological Park, Orissa. J. Vet. Parasitol.24: 111-115.

MALAN F.S., HORAK I.G., VOS V. and VAN WIK J.A. 1997. Wildlife parasites: lessons for parasites control in livestock. Vet. Parasitol.71:137-153.

NUNN, C.L., LINDENFORS, P., PURSALL, E.R. and ROLFF, J. 2009. On sexual dimorphism in immune function. Philos. Trans. R. Soc. Lond., B, Biol. Sci. 364(1513): 61-69.

PATTON, S., RABINOWITZ, A., RADOLPH, S. and JOHNSON, S.S. 1986. A coprological survey of parasites of Neotropical Felidae. J. Parasitol. 72: 517-520.

PRICE K.R., GUERIN M.T. and BARTA J.R. 2014. Success and failure: The role of relative humidity levels and environmental management in live Eimeria vaccination of cage-reared replacement layer pullets. J. Appl. Poult. Res. 23: 523-535

RAUSCH, R. L. 1954. Studies on the helminth fauna of Alaska. XXI. Taxonomy, morphological variation, and ecology of Diphyllobothrium lursi n. sp. provis. on Kodiak Island. J. Parasitol.40: 540-563

RAUSCH, R.L., BABERO, B.B., RAUSCH, R.V. and SCHILLER, E.L. 1956. Studies on the helminth fauna of Alaska. XXVII. The occurrence of larvae of Trichinella spiralis in Alaskan mammals. J. Parasitol.42: 259-271.

RAVINDRAN, R., KUMAR, K.G.A. and GAFOOR, V.M.A. 2011. Parasitic infections in wild animals of Kerala. Zoos' Print 26: 34.

SCHMIDT, G.D. and ROBERTS, L.S. 1996. Foundations of Parasitology. Times Mirror Company. USA. 
SCHULTE-HOSTEDDE, A.I. and MASTROMONACO, G.F. 2015. Integrating evolution in the management of captive zoo populations. Evol. Appl.8(5): 413-422.

SHIRBHATE, M.V. 2006. Predator-Prey relationship and Parasitic infections in Wild animals from Melghat Tiger Reserve. PhD Thesis, Sant Gadge Baba Amravati University, Amravati. 302p.

SIMON, A.K., HOLLANDER, G.A. and MCMICHAEL, A. 2015. Evolution of the immune system in humans from infancy to old age. Proc. R. Soc. Lond., B, Biol. Sci.282: 20143085.

SINGH, P., GUPTA, M.P., SINGLA, L.D., SINGH, N. and SHARMA, D.R. 2006. Prevalence and chemotherapy of gastrointestinal helminthic infections in wild carnivores of Mahendra Choudhury Zoological Park, Punjab. J. Vet. Parasitol.20: 17-23.

SMITH, K.F., ACEVEDO-WHITEHOUSE and PEDERSEN, A.B. 2009. The role of infectious diseases in biological conservation. Anim. Conserv.12: 1-12.

SOULSBY, E.J.L. 1982. Helminths, Arthropods and Protozoa of Domesticated Animals. 7th Edition. Bailliere and Tindal, London, 766-771 pp.

STILES, C.W. and BAKER, C.E. 1935. Key-catalogue of parasites reported for Carnivora (cats, dogs, bears, etc.) with their possible public health importance. U.S.Natl. Inst. Health Bull.163: 913-1223.

WORLEY, D.E., FOX, J.C., WINTERS, J.B., JACOBSON, R.H. and GREER, K.R. 1976. Helminth and arthropod parasites of grizzly and black bears in Montana and adjacent areas. In Proc. Third Inter. Conf. on Bears. New York, Intext Press.

ZUK, M. and MCKEAN, K.A. 1996. Sex differences in parasite infections: patterns and processes. Int. J. Parasitol.26: 1009-1023.

(Manuscript received on 12 February 2020 revised on 23 April 2020) 